\title{
Cloning approach and functional analysis of anti-intimin single-chain variable fragment (scFv)
}

\author{
Márcio A Menezes ${ }^{1 \dagger}$, Karina A Aires ${ }^{1 \dagger}$, Christiane Y Ozaki ${ }^{1}$, Renato M Ruiz ${ }^{1}$, Milton CA Pereira ${ }^{1}$, Patrícia AE Abreu', \\ Waldir P Elias ${ }^{1}$, Oscar HP Ramos ${ }^{2}$, Roxane MF Piazza ${ }^{1 *}$
}

\begin{abstract}
Background: Intimin is an important virulence factor involved in the pathogenesis of enteropathogenic Escherichia coli (EPEC) and enterohemorrhagic Escherichia coli (EHEC). Both pathogens are still important causes of diarrhea in children and adults in many developing and industrialized countries. Considering the fact that antibodies are important tools in the detection of various pathogens, an anti-intimin IgG2b monoclonal antibody was previously raised in immunized mice with the conserved sequence of the intimin molecule (int ${ }_{388-667}$ ). In immunoblotting assays, this monoclonal antibody showed excellent specificity. Despite good performance, the monoclonal antibody failed to detect some EPEC and EHEC isolates harboring variant amino acids within the 338-667 regions of intimin molecules. Consequently, motivated by its use for diagnosis purposes, in this study we aimed to the cloning and expression of the single-chain variable fragment from this monoclonal antibody (scFv).
\end{abstract}

Findings: Anti-intimin hybridoma mRNA was extracted and reversely transcripted to CDNA, and the light and heavy chains of the variable fragment of the antibody were amplified using commercial primers. The amplified chains were cloned into PGEM-T Easy vector. Specific primers were designed and used in an amplification and chain linkage strategy, obtaining the scFv, which in turn was cloned into PAE vector. E. coli BL21(DE3)pLys strain was transformed with pAE scFv-intimin plasmid and subjected to induction of protein expression. Anti-intimin scFv, expressed as inclusion bodies (insoluble fraction), was denatured, purified and submitted to refolding. The protein yield was $1 \mathrm{mg}$ protein per $100 \mathrm{~mL}$ of bacterial culture. To test the functionality of the scFv, ELISA and immunofluorescence assays were performed, showing that $275 \mathrm{ng}$ of scFv reacted with $2 \mathrm{mg}$ of purified intimin, resulting in an absorbance of 0.75 at $492 \mathrm{~nm}$. The immunofluorescence assay showed a strong reactivity with EPEC E2348/69.

Conclusion: This study demonstrated that the recombinant anti-intimin antibody obtained is able to recognize the conserved region of intimin ( $\left(\mathrm{nt}_{388-667}\right)$ in purified form and the EPEC isolate.

\section{Background}

Intimin, a 94-kDa outer membrane protein, mediates the adhesion of enteropathogenic Escherichia coli (EPEC) and enterohemorrhagic Escherichia coli (EHEC) to enterocytes. Both enteropathogens are important causative agents of diarrhea. Besides, EHEC can cause acute gastroenteritis and hemorrhagic colitis [1], and produce severe/fatal renal and neurological complications as a

\footnotetext{
* Correspondence: roxane@butantan.gov.br

+ Contributed equally

'Laboratório de Bacteriologia, Instituto Butantan, Avenida Vital Brazil, 1500,

São Paulo, SP, 05503-900, Brazil

Full list of author information is available at the end of the article
}

result of the translocation of Shiga toxins (Stx1 and Stx2) across the intestinal wall.

Intimin is encoded by the E. coli attaching and effacing (eae) gene, which is required for intimate adhesion to epithelial cells and cytoskeletal reorganization [2]. The variable 280-amino acid C-terminal sequence of intimin (Int280) defines many different intimin subtypes [3-5], and up to now, several types and subtypes of intimin have been described and designated by Greek letters $[4,6-17]$. In contrast, the N-terminal region of the intimin molecule is conserved and, therefore, has been used as a target for diagnostic purposes [4,18-20].

Monoclonal antibodies have been used as tools for the detection of different pathogen antigens due to their

\section{Ciomed Central}


homogeneity and their unlimited production [21]. Antiintimin IgG2b monoclonal antibody was raised in immunized mice with purified conserved intimin (int ${ }_{388}$ 667). In immunoblotting assays, it showed excellent specificity and reacted with several serotypes of EPEC isolates. Despite good performance, the monoclonal antibody failed to detect some EPEC and EHEC isolates expressing different intimin subtypes, especially the gamma subtype [20]. In addition, monoclonal production from hybridoma is expensive and requires cell culture facilities.

Recombinant antibody (rAb) technologies involving the handling of key antibody domains constitute an option and have been increasingly used as alternatives to monoclonal antibodies (mAbs) in medical diagnostic and therapeutic applications [22]. A variety of rAb formats have been modified for specific applications, including engineered modifications to antigen binding, valency, and molecular weight (MW). One of the most popular types of rAbs is single-chain variable fragment $(\mathrm{scFv})$, as it has been successfully modified into a number of different $\mathrm{Ab}$ formats and is easily expressed by several expression systems.

Several different molecular display formats have also been described, including phage-display [23], ribosome display [24,25] and cell-surface display [26], by which antigen-reactive Abs can be selected and affinity matured. Usually, E. coli is the bacterial production system of choice for small nonglycosylated rAb fragments, including $\mathrm{scFv}$ [27].

Regarding diarrheagenic E. coli, recombinant antibodies were developed against different virulence factors, which were developed for different purposes. Kühne et al. [28] produced recombinant antibodies that recognize EspA and intimin of EHEC O157:H7. These antibodies were converted to $\mathrm{scFv}$ format and cloned into pET22b vector. By immunoblotting, the anti-intimin scFv produced revealed the exclusive recognition of intimin gamma. The anti-EspA scFv produced relatively weak signals in immunoblotting against EspA in whole-cell preparations from serotypes $\mathrm{O} 157$ and $\mathrm{O} 111$, and no signals were produced with O127 or O86 [28].

For the treatment of bovine colibacillosis caused by enterotoxigenic E. coli (ETEC), Bhaskaran et al. [29] developed a recombinant anti-F5 scFv fragment that inhibits the hemmaglutination of horse red blood cells by 55 protein, which would be expected to inhibit the binding of F5-expressing ETEC to intestinal cells. According to these authors, it would provide an effective, less expensive and animal-friendly alternative as a prophylactic agent against colibacillosis. Also for ETEC, but concerning anti-LT monoclonal antibodies, Chung et al. [30] selected scFvs that specifically reacted with intermediate forms of the $B$ subunit of
LT toxin, with the potential to be used to study pentamer assembly in vivo. Thus, the generation of scFvs with differential binding specificities opens up key areas for the development of new therapeutics that can block toxin formation in situ and thus be used for the treatment of diarrheal diseases caused by E. coli and Vibrio cholerae [30].

Prompted by the potential applications of rAb, we studied the cloning and expression and structural and functional analysis of the recombinant form ( $\mathrm{scFv}$ ) of monoclonal anti-intimin IgG2b antibody, previously obtained from animal immunization employing conserved intimin.

\section{Methods}

\section{Microorganisms and plasmids}

E. coli JM 109 [31] was used for cloning techniques and as negative control for intimin expression. E. coli BL21 (DE3)pLys or E. coli C43(DE3) were used to express the recombinant protein. EPEC E2348/69 was used as intimin expression control. $p G E M-T$ Easy vector for cloning was acquired from Promega (Madison, WI, USA). The pAE expression vector was used for expression of recombinant proteins fused with six histidine residues for nickel affinity chromatography [32].

\section{Cloning of single-chain variable fragment (scFv) of monoclonal anti-intimin antibody}

Protocols for DNA manipulation were used as described in [31]. Briefly, mRNA was extracted (Ilustra Quickprep mRNA Purification Kit - GE Healthcare, UK) and reversely transcripted to cDNA (First Strand cDNA Synthesis Kit - GE Healthcare, UK) from anti-intimin hybridoma cells [20] cultivated in RPMI medium (Invitrogen, Brazil) plus $10 \%$ fetal bovine serum in culture flasks (TPP, Switzerland) at $37^{\circ} \mathrm{C}$ in $5 \% \mathrm{CO}_{2}$. Commercially available primers [Light primer mix, Heavy primer1, Heavy primer 2 (GE Healthcare, UK)] were employed to amplify the variable domain of heavy $(\mathrm{VH})$ and light $(\mathrm{VL})$ chains of the antibody following the manufacturer's instructions. The cDNA inserts corresponding to $\mathrm{VL}$ and $\mathrm{VH}$ were cloned into the $p G E M-T$ Easy vector and sequenced using M13 forward primer (5'-GTAAAACGACGCCCAG-3') and reverse primer (5'-CAGGAAACAGCTATGAC-3'). One set of primers was designed to amplify the heavy chain variable domain, where the forward primer was complementary to the 5' terminal region of the chain and the reverse primer was complementary to the 5' terminal region of the linker (DNA fragment that encodes the $\left[\mathrm{Gly}_{4} \mathrm{Ser}\right]_{3}$ flexible linker that joins the heavy and light chain variable domains). Also, another set of primers was designed to amplify the light chain variable domain, where the forward primer was complementary to the 3' terminal sequence of the linker 
Table 1 Primers designed for scFv cloning and annealing temperatures

\begin{tabular}{|c|c|c|}
\hline Primers & Sequence & Annealing $\mathrm{T}^{\circ}$ \\
\hline $\begin{array}{c}\text { VH } \\
\text { Forward }\end{array}$ & 5' GGATCCGTGCAGCTGCAGGAGTCTGG 3' & $60^{\circ} \mathrm{C}$ \\
\hline $\begin{array}{l}\text { VH } \\
\text { Reverse } \\
\text { Linker }\end{array}$ & $5^{\prime}$ ACCGCCTCCACCGGAGACGGTGACCGTG 3' & $76^{\circ} \mathrm{C}$ \\
\hline $\begin{array}{c}\mathrm{VL} \\
\text { Forward } \\
\text { Linker }\end{array}$ & 5' GGTGGCGGATCGGACATTGTGCTGACC 3' & $78^{\circ} \mathrm{C}$ \\
\hline $\begin{array}{c}\mathrm{VL} \\
\text { Reverse }\end{array}$ & 5' AAGCTITTAGTTTGATTTCCAGCTTGGTGCC 3' & $70^{\circ} \mathrm{C}$ \\
\hline
\end{tabular}

Heavy chain forward primer contains the restriction site BamHI (bold). At the light chain reverse primer was inserted the restriction site HindIIII (italic) and a stop codon (bold/italic).

and the reverse complementary to the 3' terminal sequence of chain.

The light chain was amplified with the linker sequence, and then, the heavy chain was amplified with the light chain-linker sequence to generate the scFv, using the primers $\mathrm{VH}$-forward and VL-reverse with the respective restriction sites (Table 1; Figure 1). Platinum Pfx DNA polymerase (Invitrogen, USA) was used in all PCR amplification reactions to obtain $\mathrm{scFv}$. The resulting 3' non-adenylated PCR product was purified using the Ilustra GFX PCR DNA and Gel Band Purification Kit (GE Healthcare, UK) as described by the manufacturer and subjected to fill-in reaction of the 3' end with dATP. Thirty microliters of DNA were used with the

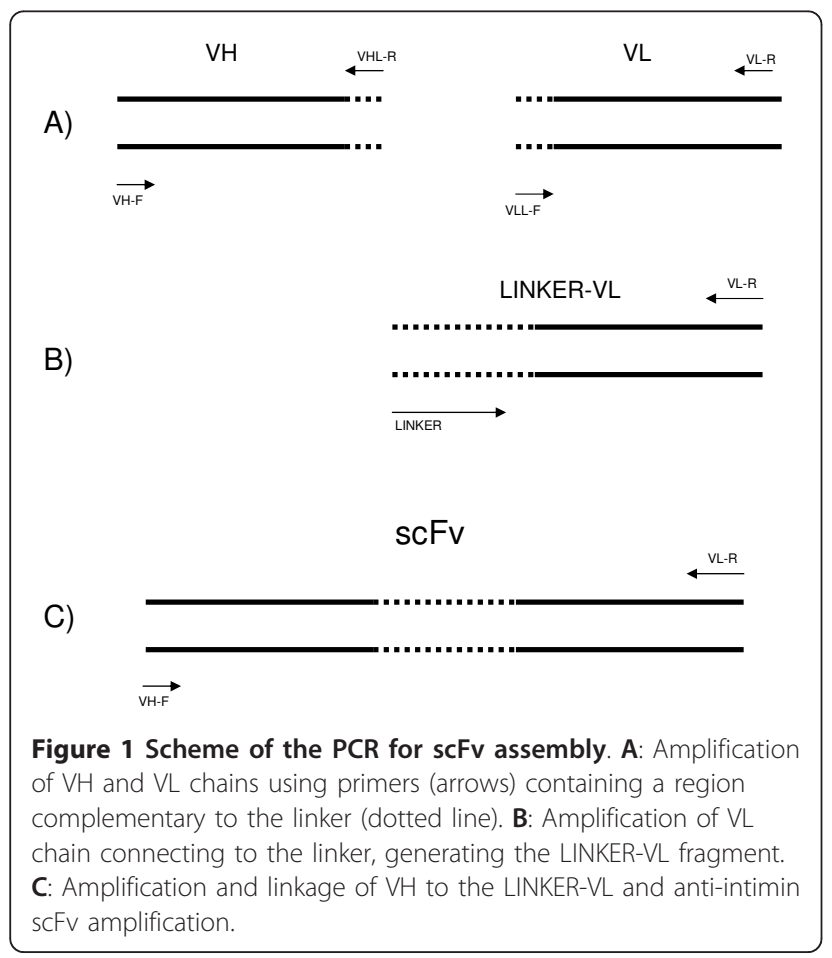

addition of $1 \mathrm{mM}$ dATP, $1 \mu \mathrm{L} \mathrm{MgCl}_{2}, 1 \mu \mathrm{L}$ of Taq DNA polymerase (Invitrogen, USA), $4 \mu \mathrm{L}$ of $10 \times$ buffer for a $40-\mu \mathrm{L}$ reaction mixture. The mixture was incubated at $72^{\circ} \mathrm{C}$ for $20 \mathrm{~min}$. After $3^{\prime}$ adenine anchoring, the DNA was cloned into $p G E M-T$ Easy and used to transform E. coli JM109 competent cells. The selected colonies were subjected to PCR to confirm the presence of the scFv insert. Purified plasmids were digested using BamHI and HindIII and the scFv fragment cloned into pAE expression vector digested with the same enzymes, for expression with an $\mathrm{N}$-terminal $6 \times$ His-Tag. $\mathrm{pAE} / \mathrm{scFv}$ vector was used for transformation of $E$. coli BL21(DE3) pLys competent cells.

\section{Recombinant antibody (anti-intimin scFv) expression, solubility and immunodetection}

pAE-scFv was introduced into E. coli BL21(DE3)pLys. The clone was cultivated $\left(37^{\circ} \mathrm{C}, 300 \mathrm{rpm}\right)$ in $400 \mathrm{ml}$ of 2YT broth containing $100 \mu \mathrm{g} / \mathrm{ml}$ ampicillin and $20 \mu \mathrm{g} /$ $\mathrm{ml}$ chloramphenicol until $\mathrm{OD}_{600}=0.5$. At this point, IPTG was added to a final concentration of $1 \mathrm{mM}$, and the culture was continued for an additional $5 \mathrm{~h}$ under the same conditions. The culture was centrifuged $(4,500$ $\times \mathrm{g}, 15 \mathrm{~min}, 4^{\circ} \mathrm{C}$ ), the pellet was resuspended in $30 \mathrm{ml}$ of PBS, pH 7.4, and the bacterial cells were disrupted in a French press under 2,000 psi (Thermo Scientific, USA). The bacterial extract was centrifuged $(12,000 \times \mathrm{g}$, $30 \mathrm{~min}, 4^{\circ} \mathrm{C}$ ), and the pellet was resuspended in $30 \mathrm{ml}$ solubilizing buffer (50 mM Tris- $\mathrm{HCl}, \mathrm{pH} 8.0 ; 200 \mathrm{mM}$ $\mathrm{NaCl} ; 5 \mathrm{mM}$ imidazole; and $8 \mathrm{M}$ urea) for $18 \mathrm{~h}$ at $4^{\circ} \mathrm{C}$ with constant mixing (100 rpm). The bacterial extract before and after induction, as well as soluble and insoluble protein fractions, was analyzed by $12 \%$ SDS/PAGE followed by Coomassie Blue staining (Bio-Rad, USA) or transferred to nitrocellulose membrane for Western blot assay (Bio-Rad, USA). The membrane containing the bacterial protein extracts was blocked with blocking buffer (5\% skim milk diluted in $\mathrm{PBS}$ ) at $37^{\circ} \mathrm{C}$ for $30 \mathrm{~min}$ and incubated with 1:3000 anti-histidine mouse antibody (GE Healthcare, UK) diluted in blocking buffer at $37^{\circ} \mathrm{C}$ for $30 \mathrm{~min}$. The membrane was washed with PBS plus 0.05\% Tween 20 (PBST) 3 times for $5 \mathrm{~min}$, followed by 1:2000 goat anti-mouse IgG conjugated to peroxidase (Zymed-Invitrogen, USA) diluted in blocking buffer at $37^{\circ} \mathrm{C}$ for $30 \mathrm{~min}$. The membrane was then washed and revealed with diaminobenzidine (DAB) plus $\mathrm{H}_{2} \mathrm{O}_{2}$.

\section{Purification and refolding of the recombinant ScFv anti- intimin antibody obtained}

The solubilized recombinant $\mathrm{scFv}$ was centrifuged $\left(12,000 \times \mathrm{g}, 4^{\circ} \mathrm{C}, 30 \mathrm{~min}\right)$ and the supernatant was purified by immobilized metal affinity chromatography (IMAC) using Ni-Sepharose resin (GE Healthcare, UK). The column was washed with solubilization buffer to 
eliminate nonspecific proteins. Next, the specific protein was eluted with elution buffer $(50 \mathrm{mM}$ Tris- $\mathrm{HCl}, \mathrm{pH}$ 8.0; $200 \mathrm{mM} \mathrm{NaCl} ; 500 \mathrm{mM}$ imidazole; and 8M urea). Purified recombinant $\mathrm{scFv}$ antibody was analyzed by 12\% SDS/PAGE, as described above.

The purified scFv was dialyzed against solubilization solution containing $5 \mathrm{M}$ urea for $12 \mathrm{~h}$ at room temperature using dialysis membrane with 8,000 Da cut-off. Step-wise dialysis was conducted by changing buffers with decreasing urea concentrations ( $3 \mathrm{M}, 2 \mathrm{M}, 1 \mathrm{M}, 0.5$ $\mathrm{M}$ and no urea). Considering the $1 \mathrm{M}$ urea step, oxidized glutathione $(375 \mu \mathrm{M})$ was added to the buffer to facilitate stable disulfide bond formation. The solubilized $\mathrm{scFv}$ was concentrated in polyethylene glycol 6000 (PEG 6000) and quantified by the Warburg-Christian method [33].

\section{Tertiary and quaternary structure predictions}

The tertiary structures of the conserved intimin N-terminal

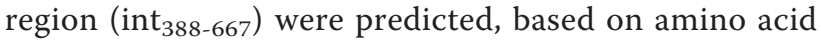
sequence deduced from published DNA sequence [GenBank:CAS11487] and anti-intimin scFv generated in the present work [GenBank:GU722326] (Table 2) using I-TASSER server http://zhang.bioinformatics.ku.edu/ I-TASSER. The quaternary structure of the complex was calculated using ZDOCK 3.0 full search [34]; http://zlab. bu.edu/zdock, following a local refinement protocol of the best evaluated model implemented in Rosetta Dock [35]; http://graylab.jhu.edu/docking/rosetta.

\section{Functionality assays}

The functionality of the purified anti-intimin scFv was assayed by ELISA and immunofluorescence.

Sandwich ELISA assay with polyclonal anti-intimin antibody A polystyrene plate MaxiSorp (Nunc, Denmark) was coated with $0.05 \mathrm{M}$ carbonate/bicarbonate buffer, $\mathrm{pH}$ 9.6, containing serial dilutions of recombinant anti-intimin scFv antibody 1:200 (1 $\mu \mathrm{g})$ to 1:1600 (125 ng) for $18 \mathrm{~h}$ at $4{ }^{\circ} \mathrm{C}$. The wells were blocked with $5 \%$ skim milk diluted in PBS buffer and then, $20 \mu \mathrm{g} / \mathrm{ml}$ purified intimin ( Int $_{388-667}$ ) was added and incubated for $2 \mathrm{~h}$ at $37^{\circ} \mathrm{C}$. The polyclonal rabbit anti-intimin IgG enriched fraction was added in serial dilutions from 1:200 (7.5 $\mu \mathrm{g})$ to $1: 3200(470 \mathrm{ng})$ and incubated for $30 \mathrm{~min}$ at $37^{\circ} \mathrm{C}$. The detection was done with goat anti-rabbit IgG conjugated to peroxidase (Invitrogen, USA) diluted 1:5000 and revealed with o-phenylenediamine (OPD). The absorbance was measured at 492 $\mathrm{nm}$ and the reaction without purified intimin was taken for background noise subtraction. Between each reaction step, washing was done with PBS buffer containing 0.05\% Tween 20. The purified intimin used in the assays was obtained as described by Menezes et al [20].

\section{Immunofluorescence}

EPEC E2348/69 was cultivated in Luria-Bertani broth (LB) at $37^{\circ} \mathrm{C}$ for $18 \mathrm{~h}$ with constant shaking (250 rpm).
Table 2 VH, linker and VL nucleotide sequence and predicted amino acid sequence of $\mathrm{VH}$, linker, $\mathrm{VL}$ and conserved intimin (Gly388 - Lys667)

\begin{tabular}{|c|c|}
\hline \multicolumn{2}{|c|}{ Nucleotide Sequences } \\
\hline CHAINS & SEQUENCES [GenBank:GU722326] \\
\hline $\mathrm{VH}$ & $\begin{array}{l}\text { GTGCAGCTGCAGGAGTCTGGACCTGAGGTGGTGAAGCC } \\
\text { TGGGACTTCAGTGAAGATATCCTGTAAGGCTTCTGGATA } \\
\text { CACGGTCACTGACTACTACATGAACTGGGTGAAGCAGAGC } \\
\text { CATGGAAAGAGCCTTGAGTGGATTGGAGATATTAATCTTG } \\
\text { ACAATCGTGATTGTAGTAATAACCAGAAGTTCCAGGACAA } \\
\text { GGCCACATTGACTGTAGACAAGTCGTCCAGCACAGTCTA } \\
\text { CATGGAGATCCGCAGCCTGACTTCTGAGGACTCTGCAGT } \\
\text { CTATTACTGTGCAAGTCAACTGGGTCACTGGGGCCAAG } \\
\text { GGACCACGGTCACCGTCTCC }\end{array}$ \\
\hline Linker & $\begin{array}{l}\text { GGTGGAGGCGGTTCAGGCGGAGGTGGCTCTGGCGGTGGC } \\
\text { GGATCG }\end{array}$ \\
\hline $\mathrm{VL}$ & $\begin{array}{l}\text { GACATTGTGCTGACCCAGTCTCCAGCTTCCTTAGCTGTATC } \\
\text { TCTGGGGCAGAGGGCCACCATCTCATACAGGGCCAGCAA } \\
\text { AAGTGTCAGTACATCTGGCTATAGTTATATGCACTGGAACC } \\
\text { AACAGAAACCAGGACAGCCACCCAGACTCCTCGTCTATCTT } \\
\text { GTATCCAACCTAGAATCTGGGGTCCCTGCCAGGTTCAGTG } \\
\text { GCAGTGGTCTGGGACAGACTCACCCTCAACATCCATCCTG } \\
\text { TGGAGGAGGAGGATGCTGCAACCTATTACTGTCAGCACAT } \\
\text { TAGGGAGCTTACACGTTCGGAGGGGGCACCAAGCTGGAAA } \\
\text { TCAAAC }\end{array}$ \\
\hline
\end{tabular}

\begin{tabular}{|c|c|}
\hline \\
\hline \multicolumn{2}{|c|}{$\frac{\text { Amino Acid Sequences }}{\text { CHAINS }}$} \\
\hline $\mathrm{VH}$ & $\begin{array}{l}\text { VQLQESGPEWKPGTSVKISCKASGYTVTDYYMNWVKQSHGKS } \\
\text { LEWIGDINLDNRDCSYNQKFQDKATLTVDKSSSTVYMEIRSLT } \\
\text { SEDSAVYYCASQLGHWGQGTTVTVS }\end{array}$ \\
\hline Linker & GGGGSGGGGSGGGGS \\
\hline$V L$ & $\begin{array}{l}\text { DIVLTQSPASLAVSLGQRATISYRASKSVSTSGYSYMHWNQQK } \\
\text { PGQPPRLLVYLVSLESGVPARFSGSGSGTDFTLNIHPVEEED } \\
\text { AATYYCQHIRELTRSEGAPSWKSN }\end{array}$ \\
\hline $\begin{array}{l}\text { Int } 388-667 \\
\text { [GenBank: } \\
\text { CAS11487] }\end{array}$ & $\begin{array}{l}\text { GIDYRHGTGNENDLLYSMQFRYQFDKPWSQQIEPQYVNELR } \\
\text { TLSGSRYDLVQRNNNIILEYKKQDILSLNIPHDINGTERSTQKIQ } \\
\text { LIVKSKYGLDRIVWDDSALRSQGGQIQHSGSQSAQDYQAILP } \\
\text { AYVQGGSNVYKVTARAYDRNGNSSNNVLLTITVLSNGQWD } \\
\text { QVGVTDFTADKTSAKADGTEAITYTATVKKNGVAQANVPVS } \\
\text { FNIVSGTAVLSANSANTNGSGKATVTLKSDKPGQWVSAKT } \\
\text { AEMTSALNANAVIFVDQTKASITEIKADK }\end{array}$ \\
\hline
\end{tabular}

One milliliter of the growth culture was centrifuged at $12,000 \times \mathrm{g}$ for $10 \mathrm{~min}$ and washed three times in PBS buffer. The pellet was permeabilized in $4 \%$ Triton X-100 under constant shaking $(200 \mathrm{rpm})$ for $10 \mathrm{~min}$ and washed twice in PBS buffer, followed by $1 \% \rho$-formaldehyde incubation for $20 \mathrm{~min}$ followed by two washes with PBS. Immunofluorescence reaction was performed using $44 \mu \mathrm{g} / \mathrm{ml}$ recombinant anti-intimin $\mathrm{scFv}$ for $1 \mathrm{~h}$ at room temperature, followed by anti-histidine mouse antibody incubation at 1:2000 dilutions for $1 \mathrm{~h}$ at room temperature. Goat anti-mouse IgG conjugated to fluorescein isothiocyanate (FITC) (Sigma, USA) at 1:100 dilution was added and the mixture incubated for $1 \mathrm{~h}$ at room temperature. One drop of the bacterial suspension was placed on a glass slide and examined with a fluorescence microscope (Axioskop-Zeiss, Germany) under $1000 \times$ magnification. As negative control, the assay was performed with E. coli K12 JM109. 


\section{Results}

\section{Cloning strategy of the recombinant anti-intimin ScFv}

The amplified fragments corresponding to $\mathrm{VL}$ and $\mathrm{VH}$ were cloned into $p G E M-T$ Easy vector and sequenced using the M13 primers (forward and reverse). The predicted amino acid sequences of VL and VH (Table 2) were analyzed in the NCBI database (blast.ncbi.nlm.nih. gov) using the BLAST tool, and a homology of over $90 \%$ was verified with the published data of the variable region of antibodies of the mice species Mus musculus. Conserved regions of heavy and light chain variable domains were used to design new primers containing appropriate restriction sites for subsequent cloning into expression vectors (Table 1 ).

Amplification products of approximately $300 \mathrm{bp}$ were obtained using these specific primers, corresponding to the variable domains of light and heavy chains ( $\mathrm{VL}$ and $\mathrm{VH}$ ). In order to obtain and connect the light and heavy chains variable domains by the linker sequence, four PCR reactions were performed, resulting in a product of approximately 700 bp (Figure 1), corresponding to the anti-intimin $\mathrm{scFv}$ (scFv-int), which was subsequently cloned into pAE expression vector. Transformed clones were screened by colony PCR and sequenced (data not shown).

\section{Expression of the recombinant anti-intimin scFv}

To confirm the presence of the recombinant $\mathrm{scFv}$ fused to 6 histidine residues in the extract of E. coli BL21

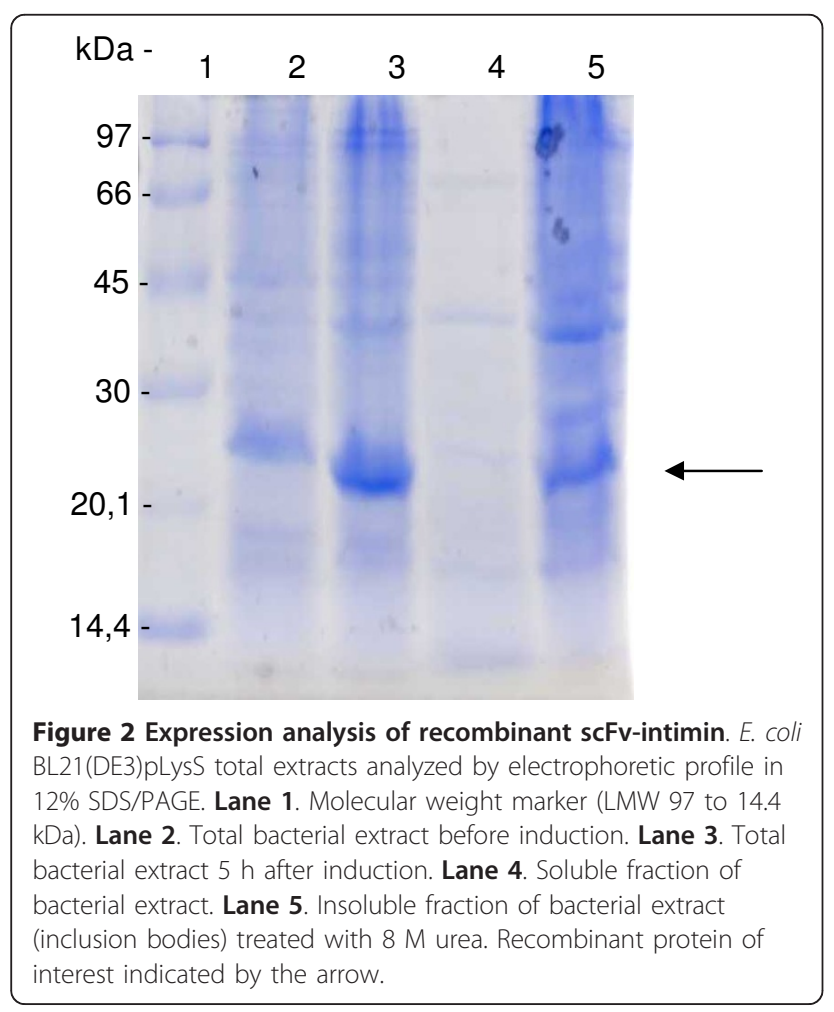

(DE3)pLys, samples were analyzed by $12 \%$ SDS/PAGE (Figure 2) and immunodetected using mouse anti-His antibody (Figure 3). The results showed the expression of a $26.5 \mathrm{kDa}$ protein, the predicted size of anti-intimin $\mathrm{scFv}$ as inclusion bodies in the post-induction fraction (Figure 2, lanes 3 and 5 and Figure 3, lanes 2 and 4).

\section{Purification of the recombinant anti-intimin ScFv}

The insoluble protein produced was solubilized using $8 \mathrm{M}$ urea buffer and purified by immobilized metal affinity chromatography (IMAC) using Ni-Sepharose resin. The purified protein was then refolded, quantified and subjected to analysis by SDS/PAGE (12\%), revealing a protein of $26.5 \mathrm{kDa}$, predicted for scFv (Figure 3, lane 4 and Figure 4 , lane 2). The final process yield was approximately $10 \mathrm{mg}$ of refolded scFv per liter of bacterial culture.

\section{Structural and functional analysis of the recombinant anti-intimin ScFv}

The overall in silico analysis of the constructed models revealed expected features corresponding to $\mathrm{scFv}$ (Figure $5 \mathrm{~A}$ ) and intimin domain arrangement that is typically found in homologous molecules (Figure 5B). Both models were subjected to calculations concerning complex formation. The final complex structure suggested that

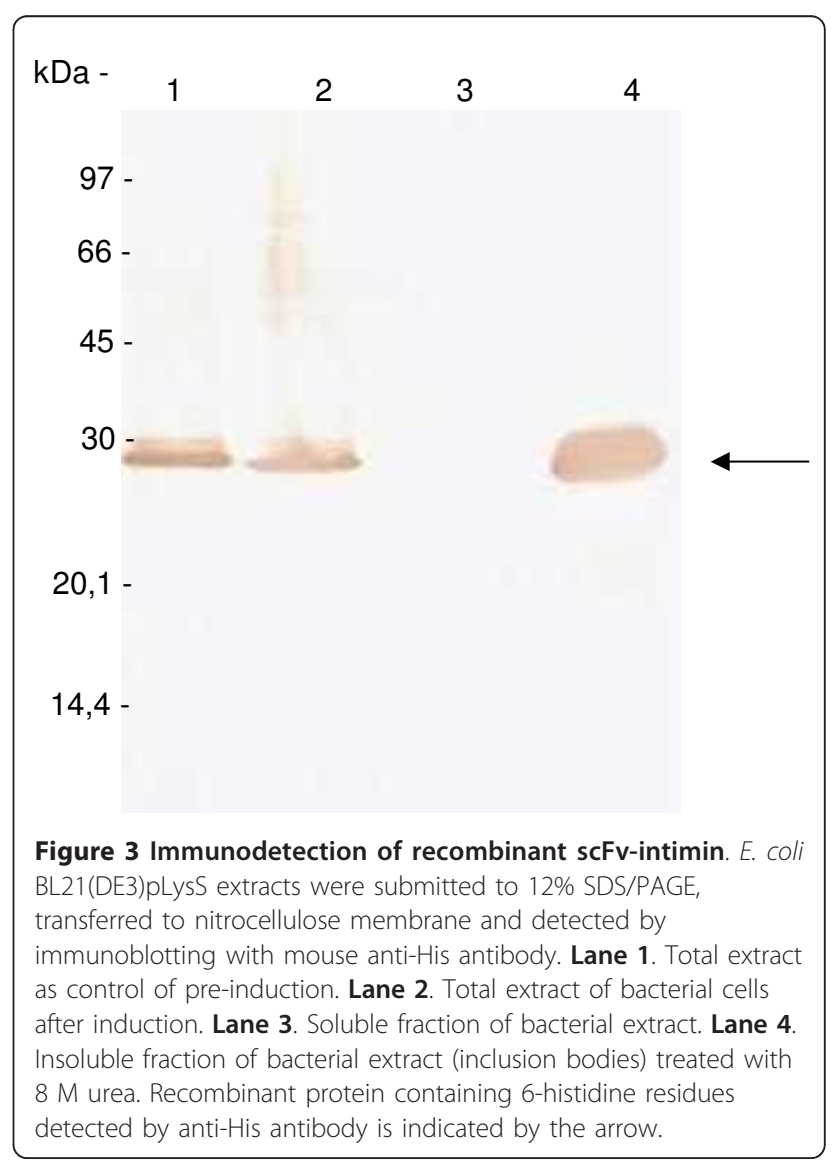




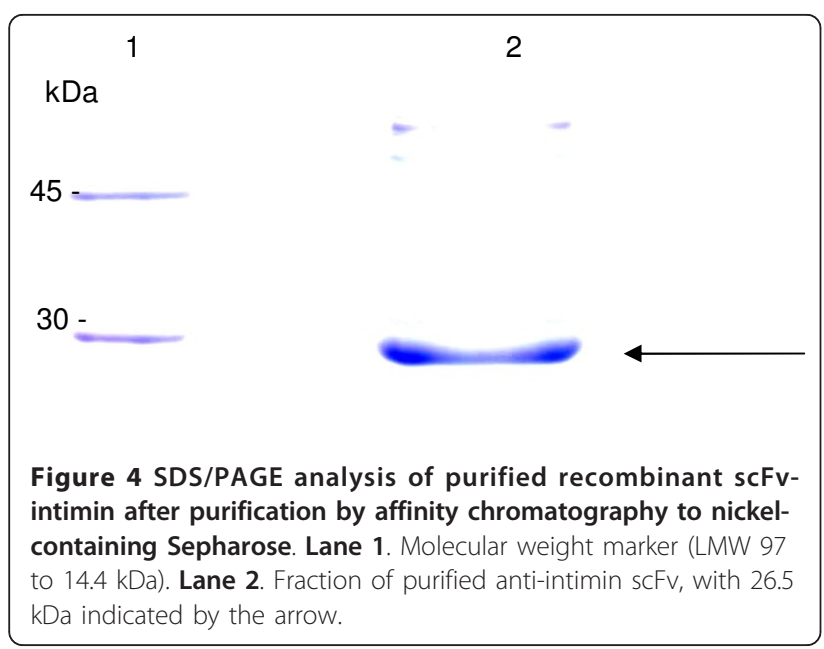

CDR-H3, CDR-L1 and CDR-L2 (the last to a lesser extent) would be mainly involved in the recognition of a region corresponding to the connection between two intimin $388-667$ Ig-like domains (Figure 5C).

The reactivity of the recombinant anti-intimin scFv was investigated by sandwich ELISA assay in a checkerboard titration. The reactivity with $2 \mu \mathrm{g}$ of purified intimin was observed until $125 \mathrm{ng}$ of scFv (data not shown). The best fit titration curve corresponded to 275 $\mathrm{ng}$ of scFv, in which the optimal absorbance was 0.75 using $7.5 \mu \mathrm{g}$ of polyclonal rabbit anti-intimin IgG enriched fraction (Figure 6). The functionality of recombinant $\mathrm{scFv}$ was tested by an immunofluorescence assay that showed a strong reactivity of the permeabilized

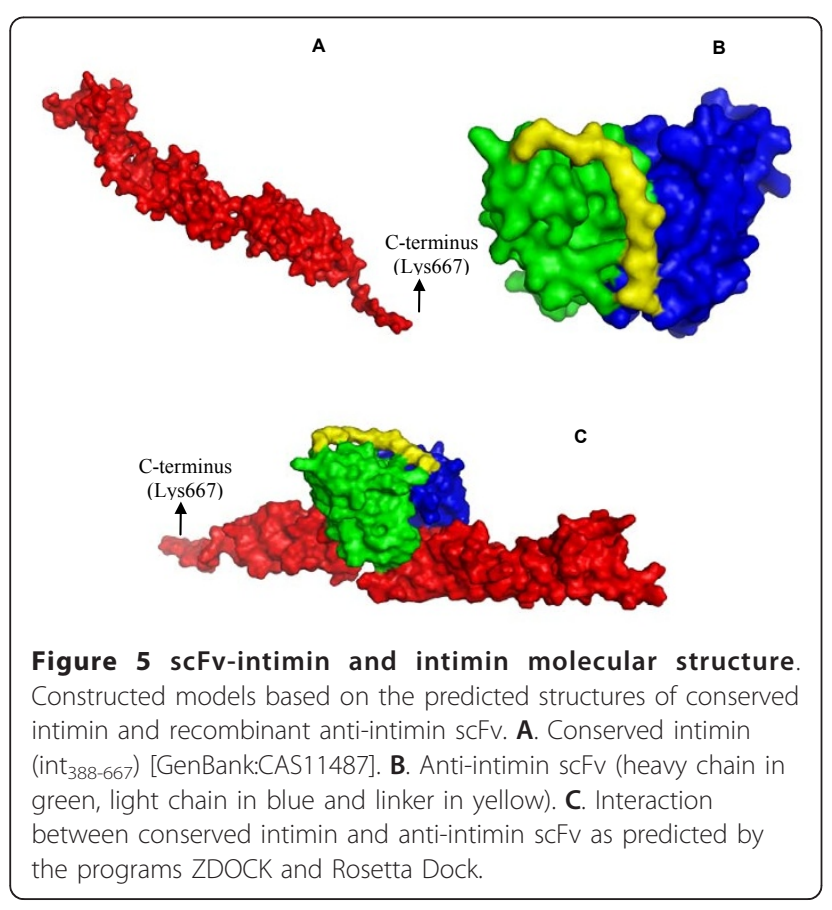

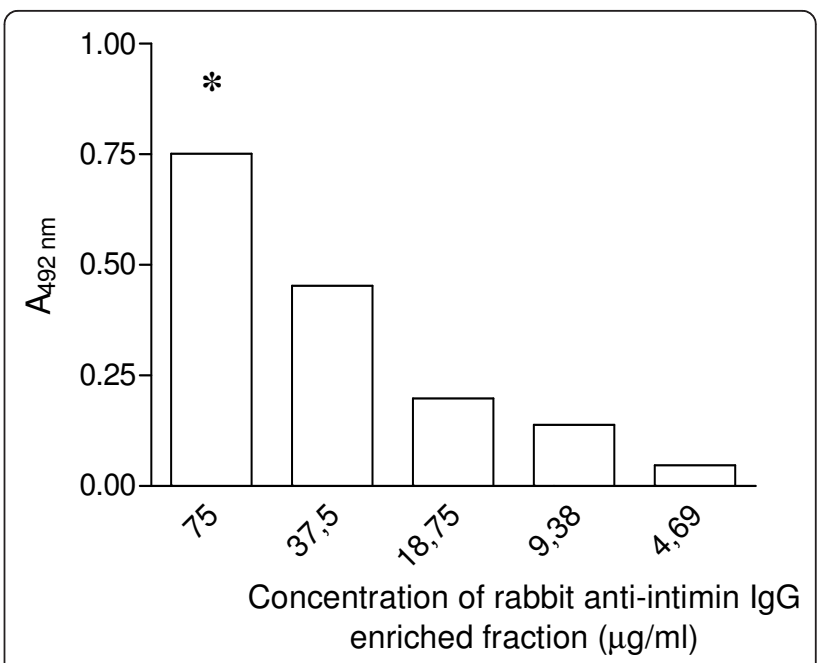

Figure 6 Functional assay of anti-intimin scFv by indirect sandwich ELISA. Microplates were coated with a serial dilution of anti-intimin scFv, followed by incubation with $2 \mu \mathrm{g} / \mathrm{mL}$ of purified intimin and a serial dilution of rabbit anti-intimin $\lg \mathrm{G}$ enriched fraction antibody. The graph shows the best fit titration curve of $275 \mathrm{ng}$ of anti-intimin scFv reacting with $2 \mu \mathrm{g}$ of purified intimin in which the optimal absorbance was defined by $7.5 \mu \mathrm{g}$ rabbit antiintimin $\lg G$ enriched fraction antibody $(*)$.

EPEC E2348/69 cells with the scFv antibody (Figure 7). As expected, the negative control, E. coli K12, was not stained using the scFv antibody. These results demonstrate that recombinant $\mathrm{scFv}$ produced in this work is functional and recognizes either the conserved region of intimin, used in the ELISA assay, or native intimin on the permeabilized EPEC E2348/69 cells.

\section{Discussion}

Serotyping has been widely applied in the diagnosis of gastrointestinal diseases caused by EPEC and EHEC, but cannot be used for identifying these groups conclusively [36]. Therefore, identification of the characteristic virulence genes is an obvious choice for detection. PCR to detect one or multiple virulence genes in the same reaction has been a successful method for the detection of EPEC and EHEC, as well as other DEC pathotypes. Nevertheless, gene detection does not assure expression of the corresponding virulence factor $[20,37,38]$. Among the methods for detection of virulence factor expression, immunoassays can be considered the first alternative, for which polyclonal and/or monoclonal antibodies are raised [19,39-41].

The great genetic diversity of intimin, demonstrated by the description of at least 27 subtypes, makes difficult its molecular detection, which is dependent on the primers sequences $[11,17]$. Moreover, a negative PCR result may not indicate that intimin is absent. For this reason the conserved region of this protein $\left(\operatorname{Int}_{388-667}\right)$ was used 

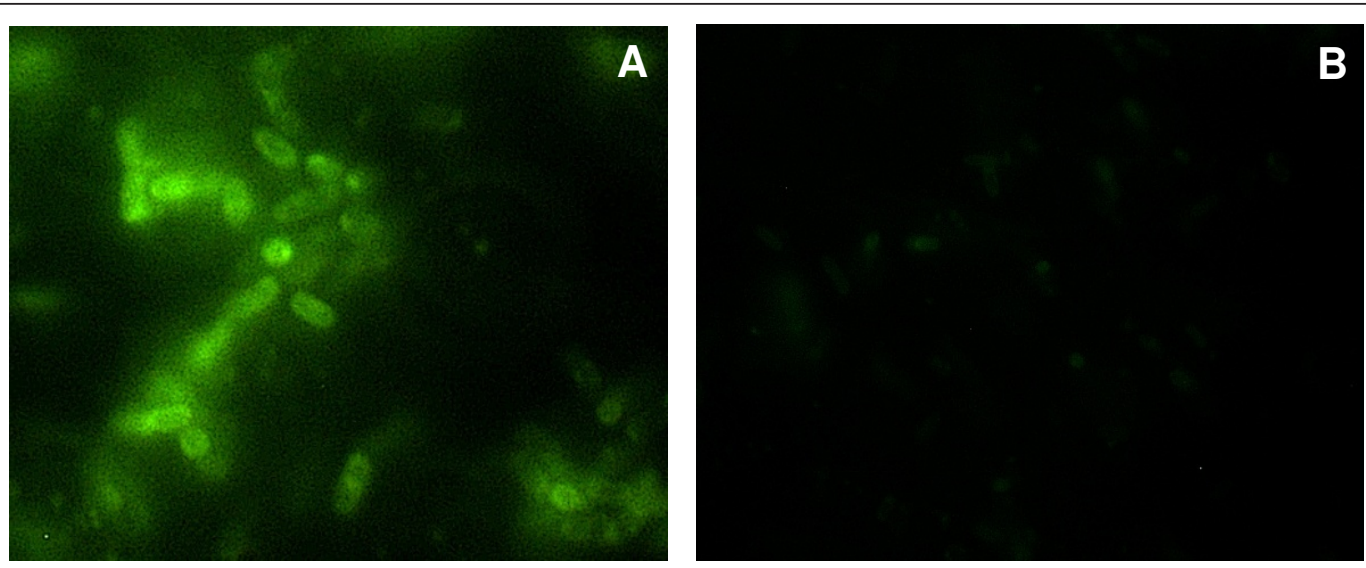

Figure 7 Functional assay of scFv-intimin by immunofluorescence. A. EPEC E2348/69 strain permeabilized with 4\% Triton X-100 followed by incubation with $4.4 \mathrm{\mu g}$ of anti-intimin scFv. The reaction was developed using anti-His antibody and anti-mouse IgG conjugated to FITC. B. E. coli K12 JM109 (negative control) assayed as described for $\mathbf{A}$.

as antigen for the development of a potential universal anti-intimin antibody able to detect the current known intimin subtypes and further uncharacterized ones [18-20].

In a previous work, even with an affinity constant of $1.3 \times 10^{-8} \mathrm{M}$ and a good detection limit with purified intimin, monoclonal anti-intimin IgG2b antibody detected $78 \%$ of a wide range of EPEC and EHEC intimin-expressing strains [20]. These promising results prompted the objective of this work, the production of a functional $\mathrm{scFv}$ (corresponding to monoclonal anti-intimin antibody) intended for diagnosis purposes.

To outline our strategy, the pAE vector was used for scFv expression which was constructed on the basis of the pRSET vector containing the origin of replication of high copy number, with the multiple cloning site containing 6 histidine residues from the pET3-His vector [32]. This vector was used successfully by others $[32,42-48]$, and despite the fact that in this study the protein was expressed in an insoluble form, a good yield was obtained.

In order to analyze the expression level of recombinant $\mathrm{scFv}$ in $E$. coli, different host strains were used, namely BL21(DE3)pLys and C43(DE3). These strains prevent the escape of expression and contribute to an over expression of the recombinant protein after induction. The analysis of expression in the C43(DE3) strain showed the presence of a protein of predicted molecular weight of $26.5 \mathrm{kDa}$, and another of smaller size (data not shown). This could be due to action of a protease that could be expressed in this strain. Another hypothesis is that the presence of rare codons in the $\mathrm{scFv}$ sequence could lead to truncated protein forms in this strain. On the other hand, despite the presence of some protein before induction, recombinant E. coli BL21(DE3)
pLys successfully expressed scFv with the expected molecular weight. These results showed that E. coli BL21(DE3)pLys expressed more protein and only the predicted one. Thus, this strain was chosen for the expression of $\mathrm{scFv}$ anti-intimin.

Expression in the reducing environment of the cytoplasm can be achieved at high concentrations but often results in the formation of inclusion bodies (i.e., reduced and unfolded proteins), where the product requires solubilization with denaturing agents (e.g., $8 \mathrm{M}$ urea) and subsequent refolding, by dialysis, of the denaturing agent in the presence of a redox pair (e.g., reduced and oxidized glutathione). Refolding efficiency varies for different antibodies [49]. The anti-intimin scFv obtained in this work was also expressed as insoluble bodies, and thus, it was necessary to perform denaturing solubilization with subsequent refolding steps.

The method chosen for recovering insoluble protein was the solubilization in Tris- $\mathrm{HCl}$ buffer containing $8 \mathrm{M}$ urea, followed by purification and step-wise dialysis for the refolding of the purified protein by decreasing urea concentration. Anti-intimin $\mathrm{scFv}$ was expressed with 6 histidine residues at the $\mathrm{N}$-terminal, for the purpose of purification by metal affinity. In addition to purification, the His-tag is an epitope for detection using specific antibodies. To demonstrate the functionality of the $\mathrm{scFv}$ by ELISA, purified intimin conserved domain ( Int $_{388-667}$ ) is the best reagent for detection. However, the simple fact that the purified intimin also contains His-tag clearly impairs scFv detection, since the former could create false positive results.

To overcome this technical limitation, the strategy used was the sandwich indirect ELISA assay using the rabbit IgG enriched fraction or monoclonal anti-intimin. This protocol consisted of coating the plate with anti- 
intimin scFv, followed by incubation with purified intimin and rabbit polyclonal anti-intimin IgG, without the use of anti-His. Results showed that anti-intimin scFv is a functional antibody, and as expected, the polyclonal antibody does not compete with the scFv for the same epitope. On the other hand, no reactivity was observed when the monoclonal anti-intimin antibody was used, suggesting that this antibody competes with the scFv for the same intimin epitope (data not shown). Moreover, anti-intimin $\mathrm{scFv}$ was tested by immunofluorescence. This antibody recognized the EPEC E2348/69 strain but not $E$. coli $\mathrm{K}-12$ after outer membrane permeabilization, showing its specificity for intimin.

The results of this study allow us to conclude that recombinant anti-intimin scFv was able to recognize the conserved region of purified intimin ( Int $_{388-667}$ ) and intimin in an EPEC isolate. Subsequent tests underway in our laboratory could demonstrate if the scFv reacts with the different types of intimin expressed by EPEC and EHEC. These data will be extremely important, since the recombinant $\mathrm{scFv}$ described so far is derived from spleen cell-cDNA from rabbits immunized with the intimin variable portion of O157:H7 and recognize only gamma intimin [28]. It is worth mentioning that our previous results already showed that monoclonal anti-intimin antibody recognizes a broad variety of EPEC and EHEC strains [20], and as the anti-intimin $\mathrm{scFv}$ described herein is derived from it, this $\mathrm{rAb}$ is a promising tool for EPEC/EHEC diagnosis.

\section{Conclusions}

In conclusion, we successfully obtained a recombinant anti-intimin $s c F v$ with high specificity for intimin, detecting the conserved region of intimin $\left(\mathrm{Int}_{388-667}\right)$ in the purified form and intimin on an EPEC isolate. Thus, this $\mathrm{rAb}$ is a very promising tool for EPEC/EHEC diagnosis and research purposes. Also, the deduced amino acid sequences of CDRs may also help us to create other scFv fragments with even higher affinity and specificity for intimin by site-directed mutagenesis.

\footnotetext{
Abbreviations

EPEC: enteropathogenic Escherichia coli; EHEC: enterohemorrhagic Escherichia coli; ETEC: enterotoxigenic Escherichia coli; eae: E. coli attaching and effacing; Ab: antibody; rAb: recombinant antibody; mAb: monoclonal antibody; MW: molecular weight; scFv: single chain variable fragment; $\mathrm{VH}$ : heavy chain variable domain; VL: light chain variable domain; EspA: E. coli secreted protein A; LT: heat-labile toxin; cDNA: complementary DNA; NCBI: National Center for Biotechnology Information; BLAST: Basic Local Alignment Search Tool; PCR: polymerase chain reaction; IMAC: immobilized metal affinity chromatography; SDS: sodium dodecyl sulfate; PAGE: polyacrylamide gel electrophoresis; CDR: complementarity determining region; ELISA: enzymelinked immunosorbent assay; RPAS: recombinant phage antibody system; His: histidine; IPTG: isopropyl $\beta$-D-thiogalactopyranoside; RPMI: Roswell Park Memorial Institute; dATP: deoxiadenosine triphosphate; PBS: phosphatebuffered saline; PBST: PBS plus Tween 20; DAB: diaminobenzidine; PEG: polyethylene glycol; OPD: o-phenylenediamine; LB: Luria-Bertani broth; FITC: fluorescein isothiocyanate.
}

\section{Acknowledgements}

This work was supported by Fundação de Amparo à Pesquisa do Estado de São Paulo (Grants 04/12136-5 and fellowship to MAM) and FINEP.

\section{Author details}

'Laboratório de Bacteriologia, Instituto Butantan, Avenida Vital Brazil, 1500, São Paulo, SP, 05503-900, Brazil. ${ }^{2}$ CEA, iBiTecs, SIMOPRO, Gif sur Yvette, France.

\section{Authors' contributions}

MAM and KAA contributed equally to this work, performing all cloning approaches and protein expression, and contributed to the preparation of the manuscript. CYO contributed to the molecular study, performed all the ELISA assays, and contributed to the preparation of the manuscript. RMR and PAEA contributed to the molecular assays. MCAP performed all immunofluorescence assays. WPE contributed to the preparation of the manuscript and critically reviewed it. OHPR contributed to the tertiary and quaternary structure predictions and to the preparation of the manuscript. RMFP conceived and designed the study and oversaw the preparation of the manuscript. All authors read and approved the final manuscript.

\section{Competing interests}

The authors declare that they have no competing interests.

Received: 27 August 2010 Accepted: 2 February 2011

Published: 2 February 2011

\section{References}

1. O'Brien AD, Newland JW, Miller SF, Holmes RK, Smith HW, Formal SB: Shigalike toxin-converting phages from Escherichia coli strains that cause hemorrhagic colitis or infantile diarrhea. Science 1984, 226:694-696.

2. Jerse $A E, Y u J, T a l l ~ B D$, Kaper JB: A genetic locus of enteropathogenic Escherichia coli necessary for the production of attaching and effacing lesions on tissue culture cells. Proc Natl Acad Sci USA 1990, 87:7839-7843.

3. Frankel G, Candy DC, Everest P, Dougan G: Characterization of the Cterminal domains of intimin-like proteins of enteropathogenic and enterohemorrhagic Escherichia coli, Citrobacter freundii, and Hafnia alvei. Infect Immun 1994, 62:1835-1842.

4. Adu-Bobie J, Trabulsi LR, Carneiro-Sampaio MMS, Dougan G, Frankel G: Identification of immunodominant regions within the C-terminal cell binding domain of intimin $\alpha$ an intimin $\beta$ from enteropathogenic Escherichia coli. Infect Immun 1998, 66:5643-5649.

5. Lacher DW, Steinsland H, Whittam TS: Allelic subtyping of the intimin locus (eae) of pathogenic Escherichia coli by fluorescent RFLP. FEMS Microbiol Lett 2006, 261:80-87.

6. Agin TS, Wolf MK: Identification of a family of intimins common to Escherichia coli causing attaching-effacing lesions in rabbits, humans, and swine. Infect Immun 1997, 65:320-326.

7. China B, Jacquemin E, Devrin AC, Pirson V, Mainil J: Heterogeneity of the eae genes in attaching/effacing Escherichia coli from cattle: comparison with human strains. Res Microbiol 1999, 150:323-332.

8. Reid SD, Betting DJ, Whittam TS: Molecular detection and identification of intimin alleles in pathogenic Escherichia coli by multiplex PCR. J Clin Microbiol 1999, 37:2719-2722.

9. Oswald E, Schmidt H, Morabito S, Karch H, Marches O, Caprioli A: Typing of intimin genes in human and animal enterohemorrhagic and enteropathogenic Escherichia coli: characterization of a new intimin variant. Infect Immun 2000, 68:64-71.

10. Tarr CL, Whittam TS: Molecular evolution of the intimin gene in 0111 clones of pathogenic Escherichia coli. J Bacteriol 2002, 184:479-487.

11. Zhang WL, Köhler B, Oswald E, Beutin L, Karch H, Morabito S, Caprioli A, Suerbaum S, Schmidt H: Genetic diversity of intimin genes of attaching and effacing Escherichia coli strains. J Clin Microbiol 2002, 40:4486-4492.

12. Ramachandran V, Brett K, Hornitzky MA, Dowton M, Bettelheim KA, Walker MJ, Djordjevic SP: Distribution of intimin subtypes among Escherichia coli isolates from ruminant and human sources. J Clin Microbiol 2003, 41:5022-5032.

13. Beutin L, Krause G, Zimmermann S, Kaulfuss S, Gleier K: Characterization of Shiga toxin-producing Escherichia coli strains isolated from human patients in Germany over a 3-year period. J Clin Microbiol 2004, 42:1099-1108. 
14. Garrido P, Blanco M, Moreno-Paz M, Briones C, Dahbi G, Blanco J, Blanco J, Parro V: STEC-EPEC oligonucleotide microarray: a new tool for typing genetic variants of the LEE pathogenicity island of human and animal Shiga toxin-producing Escherichia coli (STEC) and enteropathogenic E. coli (EPEC) strains. Clin Chem 2006, 52:192-201.

15. Blanco JE, Blanco M, Alonso MP, Mora A, Dahbi G, Coira MA, Blanco J: Serotypes, virulence genes, and intimin types of Shiga toxin (verotoxin)producing Escherichia coli isolates from human patients: prevalence in Lugo, Spain, from 1992 through 1999. J Clin Microbiol 2004, 42:311-319.

16. Blanco M, Schumacher S, Tasara T, Zweifel C, Blanco JE, Dahbi G, Blanco J, Stephan R: Serotypes, intimin variants and other virulence factors of eae positive Escherichia coli strains isolated from healthy cattle in Switzerland. Identification of a new intimin variant gene (eae-eta2). BMC Microbiol 2005, 5:23.

17. Blanco M, Blanco JE, Dahbi G, Alonso MP, Mora A, Coira MA, Madrid C, Juárez A, Bernárdez MI, González EA, Blanco J: Identification of two new intimin types in atypical enteropathogenic Escherichia coli. Int Microbiol 2006, 9:103-110.

18. Batchelor M, Knutton S, Caprioli A, Huter V, Zanial M, Dougan G, Frankel G Development of a universal intimin antiserum and PCR primers. J Clin Microbiol 1999, 37:3822-3827.

19. Koga PCM, Menezes CA, Lima FA, Nara JM, Magalhães CA, Cianciarullo AM, Ferreira-Júnior JMC, Trabulsi LR, Mendes-Ledesma MRB, Piazza RMF: Polyclonal anti-intimin antibody: immunological characterization and its use in EPEC diagnosis. Braz J Microbiol 2003, 34:5-7.

20. Menezes MA, Rocha LB, Koga PC, Fernandes I, Nara JM, Magalhães CA, Abe CM, Ayala CO, Burgos YK, Elias WP, Castro AF, Piazza RM: Identification of enteropathogenic and enterohaemorrhagic Escherichia coli strains by immunoserological detection of intimin. J Appl Microbiol 2010, 108:878-887.

21. Svennerholm AM, Wikström M, Lindbald M, Holmgren J: Monoclonal antibodies against Escherichia coli heat-stabile toxin (STa) and their use in a diagnostic ST ganglioside GM1-Enzime-linked immunosorbent assay. J Clin Microbiol 1986, 24:585-590.

22. Weisser NE, Hall JC: Applications of single-chain variable fragment antibodies in therapeutics and diagnostics. Biotechnol Adv 2009, 27:502-520.

23. McCafferty J, Griffiths AD, Winter G, Chiswell DJ: Phage antibodies: filamentous phage displaying antibody variable domains. Nature 1990, 348:552-554

24. Hanes J, Plückthun A: In vitro selection and evolution of functional proteins by using ribosome display. Proc Natl Acad Sci USA 1997, 94:4937-4942.

25. He M, Taussig MJ: Antibody-ribosome-mRNA (ARM) complexes as efficient selection particles for in vitro display and evolution of antibody combining sites. Nucleic Acids Res 1997, 25:5132-5134.

26. Francisco JA, Stathopoulos C, Warren RA, Kilburn DG, Georgiou G: Specific adhesion and hydrolysis of cellulose by intact Escherichia coli expressing surface anchored cellulase or cellulose binding domains. Biotechnology (N Y) 1993, 11:491-495.

27. Wang SH, Zhang JB, Zhang ZP, Zhou YF, Yang RF, Chen J, Guo YC, You F, Zhang XE: Construction of single chain variable fragment (ScFv) and BiscFv-alkaline phosphatase fusion protein for detection of Bacillus anthracis. Anal Chem 2006, 78:997-1004.

28. Kühne SA, Hawes WS, La Ragione RM, Woodward MJ, Whitelam GC, Gough KC: Isolation of recombinant antibodies against EspA and intimin of Escherichia coli 0157:H7. J Clin Microbiol 2004, 42:2966-2976.

29. Bhaskaran S, Jay CM, Berghman LR, Wagner GG, Waghela SD: A singlechain fragment variable recombinant antibody against F5 fimbria of enterotoxigenic Escherichia coli inhibits agglutination of horse red blood cells induced by F5 protein. Vet Res Commun 2005, 29:463-476.

30. Chung WY, Sack M, Carter R, Spiegel H, Fischer R, Hirst TR, Williams NA, James RF: Phage-display derived single-chain fragment variable (scFv) antibodies recognizing conformational epitopes of Escherichia coli heatlabile enterotoxin B-subunit. J Immunol Methods 2008, 339:115-123.

31. Sambrook J, Fritsch EF, Maniatis T: Molecular cloning: a laboratory manual Cold Spring Harbor Laboratory Press, Cold Spring Harbor, NY; 1989.

32. Ramos CR, Abreu PA, Nascimento AL, Ho PL: A high-copy T7 Escherichia coli expression vector for the production of recombinant proteins with a minimal N-terminal His-tagged fusion peptide. Braz J Med Biol Res 2004, 37:1103-1109.
33. Warburg $\mathrm{O}$, Christian $\mathrm{W}$ : Isolierung und kristallisation des gärungsferments enolase. Biochem Z 1942, 310:384-421.

34. Hwang H, Pierce B, Mintseris J, Janin J, Weng Z: Protein-protein docking benchmark version 3.0. Proteins 2008, 73:705-709.

35. Chaudhury S, Sircar A, Sivasubramanian A, Berrondo M, Gray JJ: Incorporating biochemical information and backbone flexibility in RosettaDock for CAPRI rounds 6-12. Proteins 2007, 69:793-800.

36. Trabulsi LR, Keller R, Gomes TAT: Typical and Atypical Enteropathogenic Escherichia coli. Emerg Infect Dis 2002, 8:508-513.

37. Vilhena-Costa AB, Piazza RM, Nara JM, Trabulsi LR, Martinez MB: Slot blot immunoassay as a tool for plasmid-encoded toxin detection in enteroaggregative Escherichia coli culture supernatants. Diagn Microbiol Infect Dis 2006, 55:101-106.

38. Nara JM, Cianciarullo AM, Culler HF, Bueris V, Horton DS, Menezes MA, Franzolin MR, Elias WP, Piazza RM: Differentiation of typical and atypical enteropathogenic Escherichia coli using colony immunoblot for detection of bundle-forming pilus expression. J Appl Microbiol 2010, 109:35-43.

39. Menezes CA, Gonçalves DS, Amianti J, Fernandes I, Taddei CR, Koga PCM, Trabulsi LR, Martinez MB, Piazza RMF: Capture immunoassay for LT detection produced by enterotoxigenic Escherichia coli in bacterial isolates. Braz J Microbiol 2003, 34:11-13.

40. Menezes CA, Imamura SY, Trabulsi LR, Fernandes-Filho A, Martinez MB, Guth BE, Girão DM, Piazza RM: Production, characterization, and application of antibodies against heat-labile type-I toxin for detection of enterotoxigenic Escherichia coli. Mem Inst Oswaldo Cruz 2006, 101:875-880.

41. Mendes-Ledesma MR, Rocha LB, Bueris V, Krause G, Beutin L, Franzolin MR, Trabulsi LR, Elias WP, Piazza RM: Production and characterization of rabbit polyclonal sera against Shiga toxins Stx 1 and Stx2 for detection of Shiga toxin-producing Escherichia coli. Microbiol Immunol 2008, 52:484-491.

42. Neves FO, Ho PL, Raw I, Pereira CA, Moreira C, Nascimento AL: Overexpression of a synthetic gene encoding human alpha interferon in Escherichia coli. Protein Expr Purif 2004, 35:353-359.

43. Reis CV, Andrade SA, Ramos OH, Ramos CR, Ho PL, Batista IF, ChudzinskiTavassi AM: Lopap, a prothrombin activator from Lonomia obliqua belonging to the lipocalin family: recombinant production, biochemical characterization and structure-function insights. Biochem J 2006, 398:295-302.

44. Silva M, Cabrera-Crespo J, Sbrogio-Almeida ME, Miyaji EN, Ho PL, Leite LC, Lopes AP: Optimizing expression of Streptococcus pneumoniae surface protein a, PspA: serocross-reactivity within families of antisera induced against clades 1 and 3. Mol Biotechnol 2007, 37:146-154.

45. Vieira ML, D'Atri LP, Schattner M, Habarta AM, Barbosa AS, de Morais ZM, Vasconcellos SA, Abreu PA, Gómez RM, Nascimento AL: A novel leptospiral protein increases ICAM-1 and E-selectin expression in human umbilical vein endothelial cells. FEMS Microbiol Lett 2007, 276:172-180.

46. Longhi MT, Oliveira TR, Romero EC, Gonçales AP, de Morais ZM, Vasconcellos SA, Nascimento AL: A newly identified protein of Leptospira interrogans mediates binding to laminin. J Med Microbiol 2009, 58:1275-1282

47. Atzingen MV, Gómez RM, Schattner M, Pretre G, Gonçales AP, de Morais ZM, Vasconcellos SA, Nascimento AL: Lp95, a novel leptospiral protein that binds extracellular matrix components and activates eselectin on endothelial cells. J Infect 2009, 59:264-276.

48. Vieira ML, de Morais ZM, Gonçales AP, Romero EC, Vasconcellos SA, Nascimento AL: Lsa63, a newly identified surface protein of Leptospira interrogans binds laminin and collagen IV. J Infect 2010, 60:52-64.

49. Guo JQ, You SY, Li L, Zhang YZ, Huang JN, Zhang CY: Construction and high-level expression of a single-chain Fv antibody fragment specific for acidic isoferritin in Escherichia coli. J Biotechnol 2003, 102:177-189.

doi:10.1186/1756-0500-4-30

Cite this article as: Menezes et al:: Cloning approach and functional analysis of anti-intimin single-chain variable fragment (scFv). BMC Research Notes 2011 4:30. 